\title{
Avenue of Spies: A True Story of Terror, Espionage, and One American Family's Heroic Resistance in Nazi-Occupied Paris. By Alex Kershaw. New York: Crown Publishers, 2015.
}

Edward J. Hagerty

American Military University

Follow this and additional works at: https://digitalcommons.usf.edu/jss

pp. $122-124$

\section{Recommended Citation}

Hagerty, Edward J.. "Avenue of Spies: A True Story of Terror, Espionage, and One American Family's Heroic Resistance in Nazi-Occupied Paris. By Alex Kershaw. New York: Crown Publishers, 2015.." Journal of Strategic Security 10, no. 2 (2017) : 122-124.

DOI: http://doi.org/10.5038/1944-0472.10.2.1601

Available at: https://digitalcommons.usf.edu/jss/vol10/iss2/9

This Book Review is brought to you for free and open access by the Open Access Journals at Digital Commons @ University of South Florida. It has been accepted for inclusion in Journal of Strategic Security by an authorized editor of Digital Commons @ University of South Florida. For more information, please contact digitalcommons@usf.edu. 
Avenue of Spies: A True Story of Terror, Espionage, and One American Family's Heroic Resistance in Nazi-Occupied Paris. By Alex Kershaw. New York: Crown Publishers, 2015. 
Hagerty: A venue of Spies

\section{Avenue of Spies: A True Story of Terror, Espionage, and One American Family's Heroic Resistance in Nazi-Occupied Paris. By Alex Kershaw. New York: Crown Publishers, 2015. ISBN:978- o-8041-4003-4. Maps. Photographs. Notes. Sources cited. Index. Pp. xviii, 286. \$28.oo.}

This summer (2017) marks the $75^{\text {th }}$ anniversary of the Vél' d'Hiv Roundup in Paris, orchestrated by SS colonel Adolf Eichmann's henchman and aide, Captain Theodor Dannecker, from his residence at number 31 Avenue Foch. Dannecker would oversee French Police round-ups of over 13,000 Jews, most of whom were deported to Auschwitz as part of the Nazi's "final solution" designed to annihilate European Jewry. Avenue Foch, one of Paris' most exclusive streets, played host not only to the infamous SS, but also to the Paris headquarters of the Gestapo at number 72. Just a short distance away at number 11 was the family home of an American doctor, Sumner Jackson, his Swiss-born wife, Charlotte, whom Jackson always called Toquette, and their teenaged son, Phillip. Dr. Jackson was the chief surgeon at the American Hospital of Paris.

Throughout the beautiful spring days of 1940, Jackson remained at the hospital treating the wounded as the Nazi juggernaut advanced on the French capital. Jackson was no stranger to the horrible wounds of war; he had volunteered in 1916 to serve with the British Royal Army Medical Corps and saw service in France. There he met Toquette, a vivacious nurse from a wellpositioned Paris family. They married in 1917 and after a brief and unsatisfactory stint in America, Toquette compelled the couple to return to Paris, where Jackson struggled to learn French and complete the training required to work as a doctor in France. He and Toquette settled down and lived the life of a well-to-do, respected medical family in the City of Light. Life was good in their villa on the leafy Avenue Foch, with summer vacations at the Normandy beaches and a country home in Enghein. That idyllic life came to an end on June 14, 1940, when the first Nazi troops entered Paris and raised a huge swastika flag over the Arc de Triomphe. A new life marked by heroism, great risk, and often by terror would unfold for the family over the next four years.

Alex Kershaw, a popular author of World War II books such as The Bedford Boys and The Longest Winter, while neither a professional historian nor an intelligence practitioner, has captured the fearsome atmosphere of Germanoccupied Paris as only an accomplished writer can do. For the purposes of our interests, his descriptions of the Jackson's family hazardous participation in 
hiding and fostering the escape of downed Allied airmen, and in allowing their home to be used as a message drop for the French Resistance, are instructive not only for what the Jackson's accomplished, but for what the Nazi occupiers overlooked virtually under their very noses. Viewing the story from both perspectives allows us to examine the successes and the failures of each. Kershaw presents the story from the Allied view as well as that of the Germans, describing Jackson's first steps in falsifying records and spiriting wounded Allied prisoners out of the hospital to safety by claiming they had died in his care. Later, Jackson would take even more dangerous steps to help others escape. For the German view, Kershaw focuses on SSStandartenführer Helmut Knochen of the Gestapo and his colleague Theo Dannecker, head of the Gestapo's Jewish Affairs Office in Paris. Those men were charged not only with implementing the "final solution" but with coordinating with the Vichy government and running networks of informants who assisted the Nazis in rounding up Jews and neutralizing French Resistance efforts.

By the summer of 1942, when the Grande Rafle, or the Great Roundup, began and thousands of Parisian Jews were herded into the Velodome d'Hiver, or Vél' d'Hiv, Jackson struggled to help the seriously ill by evacuating them to his hospital, but he was unable to foster their escape as the Germans kept too close watch and ensured prisoners were returned once they were well. The situation steeled Jackson's resolve to do what he could to undermine the Nazi regime and its Vichy collaborators. By the next year, the Jackson's were approached with a proposal to work with the resistance by allowing their home to be used as a "drop box" where intelligence documents could be passed on and ultimately provided to French intelligence officials in London. Jackson's wife became the primary point of contact with the resistance network using their home. The hazards of working with that network were tremendous. The Gestapo had stepped up its efforts to root out the resistance, their successes often owing largely to informers and double-agents.

Eventually the Jackson's were also betrayed, and the sad tale of their separation and incarceration in the spring of 1944 was marked by the uncertainty of their fate. Sumner and Phillip remained together and were eventually held in awful conditions in a concentration camp at Neuengamme. There the doctor did his best to protect his son and to assist the sick at the camp's infirmary, though seriously ill himself. Meanwhile his unfortunate wife languished in a concentration camp at Ravensbruck, Germany, each unaware of the other's fate. Remarkably, though very near death at the time of her liberation, Toquette survived. Sumner did not, but the shattered 
remnants of the family of Phillip and Toquette were eventually reunited. Toquette died at the American Hospital in 1968, and Phillip may still be living in Paris, now in his 90s. Kershaw interviewed Phillip extensively for the book.

Though Phillip's recollections along with those of a handful of other surviving witnesses to the events described were vital to the book, the nature of the secret actions of the resistance and of the Jackson's participation mean those events are sometimes not fully fleshed out. That is to be expected in such situations, but Kershaw compensates for that in a mostly effective way by expanding the story in places to describe how other, related operatives functioned in the resistance. In addition, the Nazi side of the story is documented more fully and Kershaw made good use of that. In all, the book is a useful look at the strengths and pitfalls of both resistance operations and the German counter-efforts. Though there is no in-depth description of complicated tradecraft, it is still a valid illustration of the value of human sources in countering the activities of an underground network, as well effectively illustrating the vulnerabilities those sources present to operatives.

Edward J. Hagerty, Ph.D., American Military University 